\title{
IRF6 Gene
}

National Cancer Institute

\section{Source}

National Cancer Institute. IRF6 Gene. NCI Thesaurus. Code C75616.

This gene plays a role in transcriptional regulation and the development of the palate. 